лише навчальних, а й ідейно-виховних завдань. У досліджуваний період починає широко пропагуватися досвід використання краєзнавства в навчанні історії.

\title{
Література
}

1. Вагин А. Основные вопросы методики преподавания истории в старших классах: [пособие для учителей] / А. Вагин, Н. Сперанская. - М. : Учпедгиз, 1959. 436 с. 2. Дегтярюк М. І. Використання наочних посібників на уроках історії: [методичний посібник з історії СРСР для викладачів 8 класів] / М. І. Дегтярюк. - К. : Радянська школа, 1955. - 108 с. 3. 3 досвіду екскурсійно-туристської та краєзнавчої роботи в школі. [зб. статей]. - Випуск 2. - К. : Рад. школа, 1957. - 79 с. 4.3 досвіду краєзнавчої роботи в школах та позашкільних установах Чернігівської області. Випуск 1. - Чернігів, 1957. 64 с. 5.3 досвіду краєзнавчої роботи в школі: [зб. статей]. - К. : Радянська школа, 1954. - 72 с. 6. 3 досвіду організації краєзнавчої роботи в школах Харківської області (Із збірок «На допомогу вчителеві»), - Випуск перший. - К. : Радянська школа, 1952. 76 с. 7. Лисенко М. Методика використання краєзнавчого матеріалу на уроках історії СРСР / Лисенко М. М. - К. : Рад. школа, 1961. - 202 с. 8. Милонов Н. П. Изучение истории области в средней школе: Из опыта работы / Н. П. Милонов. - М. : Госучпедиздат Мин. Просвещения РСФСР, 1960. - 176 с. 9. Наулко І. П. Методика викладання історії в середній школі / І. П. Наулко. - К. : Наукова думка, 1960. - 83 с. 10. Про навчальні програми та режим у початковій і середній школі. Постанова ЦК ВКП(б) від 25 серпня 1932 р. // Керівні матеріали про школу / [упоряд.: С. В. Бабич, В. О. Вікторов, С. П. Заволока]. - К. : Рад. шк., 1962. - С. 57-63.

УДК 378.091.212.2

Яна Гладир

\section{ПРОБЛЕМА ДОПРОФЕСІЙНОЇ ПІДГОТОВКИ ІНОЗЕМНИХ СТУДЕНТІВ У СУЧАСНІЙ ПЕДАГОГІЧНІЙ НАУЦІ: АНАЛІТИЧНИЙ ОГЛЯД}

Гладир Я. С. Проблема допрофесійної підготовки іноземних студентів у сучасній педагогічній науці: аналітичний огляд.

У статті здійснено аналітичний огляд концептуальних педагогічних праць останніх 15 років, присвячених проблемам допрофесійної підготовки іноземних студентів, визначено стан розробки проблеми в межах спеціальності «Теорія та методика професійної освіти». Приділено увагу й невітчизняним педагогічним дослідженням цього ж періоду, теоретичні концепти яких використовуються українськими науковцями.

Ключові слова: допрофесійна підготовка, іноземні студенти, дисертаційні дослідження, аналітичний огляд

Гладырь Я. С. Проблема допрофессиональной подготовки иностранных студентов в современной педагогике: аналитический обзор.

В статье сделан аналитический обзор концептуальных педагогических работ последних 15 лет, посвященных проблемам допрофессиональной подготовки иностранных студентов, обозначено состояние разработки этой научной проблемы в границах специальности «Теория и методика профессионального образования». Внимание уделяется и неотечественным исследованиям этого же периода, теоретические концепты которых используются украинскими учеными.

Ключевые слова: допрофессиональная подготовка, иностранные студенты, диссертационные исследования, аналитический обзор 
Hladyr Y. S. The problem of pre-professional training of foreign students in present pedagogy: analytical review

The article provides an analytical overview of the most conceptual and pedagogical work the last 15 years on the problems of pre-professional training of foreign students. It indicates the status of the development of this scientific problem within the boundaries of the speciality «Theory and methods of professional education». The author appeals to the most prominent foreign researches if their theoretical concepts are used by Ukrainian scientists.

Key words: pre-professional training, foreign students, thesis, analytical review

Проблема підготовки іноземних студентів не безпідставно вважається однією 3 найактуальніших у вітчизняній вищій школі, адже в сучасних умовах демографічних криз багато ВНЗ залежать від отриманої ліцензії на такий вид навчальної діяльності та від кількості бажаючих абітурієнтів-іноземців навчатися в конкретному університеті.

Знаючи 3 власного досвіду специфіку навчання іноземних студентів в українських університетах та викладацької роботи з таким контингентом, важко переоцінити роль допрофесійної підготовки, а, отже, й актуальність наукових напрацювань у вказаній галузі. Допрофесійна (або довузівська, або пропедевтична) підготовка іноземних студентів охоплює період їхнього навчання на підготовчому факультеті (або відділенні). Не буде помилковим стверджувати, що саме від якості та кількості здобутих там знань залежить не лише можливість іноземця отримати якісну професійну підготовку на 1-5 (6) курсах, але й певною мірою доля майбутнього спеціаліста, оскільки, як свідчить досвід, будь-яке педагогічне або методичне «недопрацювання» неодмінно найгіршим чином позначається на професійній підготовці студента-іноземця.

До питання систематизації педагогічних досліджень, присвячених підготовці іноземних студентів, уже звертались О. Адаменко, М. Разорьонова, а також Л. Кайдалова, Ж. Черкашина. Однак перша публікація, охоплюючи період 19902010 pр., не виокремлює допрофесійну підготовку; друга має узагальнено-оглядовий характер, будучи присвяченою здебільшого досвіду роботи конкретного підготовчого факультету й так само обмежується 2010 роком, а, отже, мета статmi - здійснити аналітичний огляд найпомітніших педагогічних здобутків останніх 15 років безпосередньо допрофесійної підготовки іноземних студентів як найважливішої складової загальної системи їхньої професійної підготовки, приділивши особливу увагу працям спеціальності «Теорія та методика професійної освіти».

Зупиняючись на найбільш вивчених аспектах теоретико-методичних засад допрофесійної підготовки іноземних студентів у зазначений період часу, передусім слід відзначити здобутки російського науковця О. Суригіна [11], основні 3 яких докторська дисертація (2000), де викладено дидактичні основи довузівської підготовки іноземних студентів у вищих навчальних закладах та видані протягом 1999-2008 рр. чотири монографії. У монографіях, зокрема, сформульовано основи теорії навчання нерідною мовою, презентовано педагогічне проектування системи довишівської підготовки іноземних студентів та ін.

За найдоцільніший шлях удосконалення системи довузівської підготовки студентів-іноземців О. Суригін уважає впровадження в практику їхнього навчання теорії навчання нерідною мовою в нерідному середовищі [11, с. 41, 43-44], структура якої, у свою чергу, стає фундаментом для педагогічного аналізу та педагогічного проектування в галузі підготовки спеціалістів-іноземців. Науковець докладно розкриває зміст принципів навчання нерідною мовою, доводить, що саме вони 
відтворюють найважливіші закономірності навчання нерідною мовою в педагогічній системі довишівської підготовки іноземців. Це передусім принципи: взаємозв'язку компонентів мети навчання; професійної спрямованості навчання; комунікативності; урахування адаптаційних процесів; урахування національно-культурних особливостей суб'єктів процесу навчання; лінгвометодичної й полікультурної компетентності викладачів [11, с. 91-92, 108].

Мета довишівської підготовки іноземних студентів має складну ієрархічну структуру, і верхні іï шари охоплює глобальна мета як здатність до пізнавальної діяльності нерідною мовою, що містить мовний, загальнонауковий та адаптаційний структурні компоненти [11, с. 163-164].

Специфічну педагогічну систему довузівської підготовки іноземних студентів дослідник бачить моделлю педагогічної системи навчання нерідною мовою. О. Суригін переконаний, що першим і водночас системоутворювальним елементом педагогічної системи $є$ іiї глобальна мета, другим елементом $є$ учні та їхні характерні особливості. А оскільки іноземні студенти мають нетипові учнівські характеристики, то й інші елементи такої системи вимагають специфічних «налаштувань»: від індивідуальних цілей навчання до нетрадиційних вимог до викладачів. Отже, запропонована науковцем модель педагогічної системи довузівської підготовки відштовхується від «нетрадиційних» особливостей іноземних студентів і врешті охоплює весь комплекс взаємопов'язаних та взаємодоповнюючих принципів теорії навчання нерідної мовою.

Цей автор установлює закономірності залежності ефективності навчання від його спрямованості на майбутню професійну діяльність (дослідник переконаний: процес навчання нерідною мовою слід будувати в контексті майбутніх професій студентів, і передусім це має позначатися на складі дисциплін довишівського етапу), а також від рівня адаптованості іноземних студентів до характерних певній академічній практиці і навчальному процесу форм навчальної діяльності.

Здобутки дослідження В. Коломієць (2001), присвяченого проблемі професійної мовленнєвої підготовки студентів-іноземців (зокрема, розгляд мовленнєвої діяльності в ігровій ситуації як провідного принципу в розвитку усного мовлення студентівіноземців; з'ясування педагогічних умов застосування комплексних дидактичних ігор у системі формування професійних мовленнєвих умінь у студентів іноземного походження; визначення ефективності цього методу тощо [3, с. 18-20], хоча й можуть використовуватися на підготовчому факультеті, усе ж загалом більше розраховані на етап професійної підготовки іноземців.

Розглядаючи пропедевтичну (довишівську) підготовку іноземних студентів як підсистему системи вищої технічної освіти, Н. Булгакова (2002) у масштабах докторського дисертаційного дослідження обгрунтувала оригінальну трискладову концепцію цілісної системи пропедевтичної підготовки формування предметних знань на основі структурування навчальних дисциплін відповідно до законів природних систем, розробила модель трикомпонентної структури пропедевтичної підготовки, модель системи освітньо-кваліфікаційних рівнів, модель циклічної системи навчальних дисциплін вищої технічної освіти тощо.

Поклавши в основу дослідження комунікативний підхід, О. Палка (2003) розробила модель підготовки іноземних студентів вищих навчальних закладів технічного профілю України до вивчення професійної лексики. Ця модель містить цільовий, змістовий, операційний i результативно-коригуючий компоненти, а іï ефективність авторка доводить у дисертації.

Питанням спеціального й цілеспрямованого щоденного формування культури 
міжетнічних відносин у студентів ВНЗ присвячена дисертація Є. Степанова (2004), де розроблено організаційно-педагогічну систему формування культури міжетнічних відносин студентів, що має стратегічну (мету і зміст виховання) і тактичну (методи, засоби, форми діяльності студентів) складові [10, с. 18].

I хоча групами педагогічного експерименту було обрано вітчизняних студентів, усе ж сформульовані цим автором концепти більш, ніж актуальні для процесу допрофесійної підготовки іноземців, адже загальновідомо, що інтернаціональні групи, особливо на підготовчому факультеті (первинному з етапів навчання), є традиційно найскладнішими та найпроблемнішими.

Проблемі формування готовності іноземних студентів інженерних спеціальностей до навчання, підвищенню ефективності навчання іноземних студентів природничим дисциплінам на допрофесійному етапі присвячене дослідження Л. Куришевої (2004). Зазначену готовність до навчання ця російська дослідниця розглядає цілісною якістю їхньої особистості, зокрема як «психолого-педагогічний феномен, який визначає включеність іноземного студента в реальні умови його навчання ... i прогнозування ним визначеної системи мотивачійних, вольових та інтелектуальних складових», а якісним рівнем іiі досягнення науковець бачить «процес засвоєння ... мови майбутньої технічної спеціальності» [5, с. 12]. Дослідниця підкреслила ключову важливість розвитку рівня готовності студентів-іноземців до подальшого навчання технічним дисциплінам та забезпечення його сукупністю обов'язкових педагогічних умов, у числі яких: системна організація процесу адаптації іноземних студентів на довузівському етапі; організація мовної адаптації у процесі формування лексико-семантичного тезауруса на матеріалі математичної термінології; включення такої діяльності в інформаційно-освітне професійно-орієнтоване середовище ВН3 [5, с. 14].

Досліджуючи формування комунікативної компетенції студентів-іноземців підготовчих факультетів у процесі навчання, Т. Дементьєва (2005), виокремлює 4 основних компоненти комунікативної компетенції зазначених студентів (мотиваційний, мовний, предметно-мовленнєвий, прагматичний), які й дозволяють досягти належного рівня комунікативної компетенції в навчально-професійній сфері [2, с. 7-8]. Науковець запропонувала відповідну технологію формування комунікативної компетенції студентів-іноземців у навчально-професійній сфері, «локальну технологію, щуо передбачае використання у певній послідовності навчально-мовленнєвих ситуацій на кожному з ї̈ взаємопов'язаних етапів (мотиваційно-иільовому, змістовно-підготовчому, комунікативно-діяльнісному та аналітико-коригуючому)» [2, с. 14]; визначила «послідовність використання навчально-мовленнєвих ситуачій, яка сприяє більш ивидкому та ефективному формуванню комунікативної компетенції» [2, с. 14].

Питання інформаційно-комп'ютерної готовності іноземних студентів до продовження навчання в російських ВНЗ дослідив В. Кузьмінов (2007). Така готовність визначена ним як «ц̧ілісна якість особистості, щуо містить специфічні, обумовлені особливостями навчання в іншомовному середовищі, якості» [4; с. 12]. Науковець запропонував своєрідну процесну модель формування названої готовності (яка «представлена системою взаємодіючих структурних елементів, при чому в якості базової прогностичної перспективної мети довузівського навчання виступає інформаційно-комп 'ютерна готовність, щзо визначає номенклатуру ичілей процесу довузівського навчання інформатиці» [4; с. 12]); концептуально обгрунтував освітню траєкторію у сфері проектування й моделювання іiі розвитку [4; с. 24].

Проблеми формування математичної компетентності іноземних студентів 
технічних спеціальностей дослідила Є. Хачатурова (2007), обравши за предмет дослідження саме процес довузівського навчання іноземних студентів математиці; убачаючи в математичних компетенціях студента-іноземця не так комплекс механічно засвоєних знань, а передусім цілісну якість особистості, що структурується складним взаємозв'язком системних компонентів.

О. Резван (2008) переконана, що розвиток пізнавальних потреб є провідним завданням навчання іноземних студентів, а саме на підготовчих факультетах воно набуває не лише особливої педагогічної значущості, але й складності, оскільки відбувається в умовах адаптації до нерідного суспільства [8, с. 1]. Педагогічними умовами, необхідними для розвитку пізнавальних потреб, дослідниця передусім називає: забезпечення комфортності навчання, використання адаптованих прийомів педагогічної техніки в процесі навчання студентів, забезпечення формування вмінь самостійної роботи [8, с. 6].

Перевагою цього дослідження, $\epsilon$, на нашу думку, той факт, що, говорячи про забезпечення комфортності навчання іноземців, авторка враховує культурологічний аспект i характеризує культурно-полярні структури особистостей арабських i китайських студентів, а також ураховує організацію навчання їхніх рідних країн [8, c. 6].

Н. Ушакова (2010) присвятила докторську дисертацію теорії підручникотворення, зокрема розробленню багатоаспектної моделі створення підручника з російської мови для іноземних студентів ВНЗ України.

Низка різноаспектних наукових праць щодо проблем допрофесійної підготовки студентів-іноземців (як одноосібно, так і у співавторстві) належить харківським науковцям С. Вараві, В. Груцяку, зокрема монографія В. Груцяка (2011) висвітлює розвиток системи довузівської освіти іноземних громадян в Україні.

Д. Порох (2011) звертається до проблеми адаптації іноземних студентів до навчання у ВНЗ України, зокрема медичних. Розглядаючи таку адаптацію як «процес активного пристосування студентів до умов життя в іншій краӥні ..., щуо включає нове ставлення до професї, навчальних норм, очінок, способів та прийомів самостійної роботи ... засвоєння та визнання особистістю иінностей, комунікативних норм та вимог нового соціального середовища» [6, с. 8-9], дисертантка обгрунтовує компоненти адаптації іноземних студентів до навчання у вищих медичних закладах України: соціокультурний, соціокомунікативний, соціопобутовий, професійний [6, с. 14], формулює показники адаптації, визначає об'єктивні критерії та рівні іï сформованості [6, с. 14-15], а також соціальнопедагогічні умови [6, с. 15]. I хоча експериментальними групами обрано групи 1 курсу, усе ж напрацювання цього дослідження, безумовно, стосуються і етапу довишівської підготовки іноземців, адже саме в цей період відбувається першопочаткова і тому найбільш відчутна адаптація іноземців до навчання у ВНЗ в усіх іiї проявах.

Питання визначення та обгрунтування педагогічних умов ефективності природничо-наукової підготовки іноземних студентів підготовчих факультетів розкриті Т. Шмоніною (2012), у ході чого було визначено структурні компоненти зазначеної природничо-наукової підготовки: мотиваційно-ціннісний (сукупність пізнавальних інтересів і навчальних мотивів), когнітивно-процесуальний (сукупність базових знань, умінь і навичок, необхідних для практичного розв'язання завдань природничо-наукового змісту), рефлексивно-аналітичний (рефлексивно-оцінна діяльність, прагнення до самоосвіти і самовдосконалення) [12, с. 17]; запропоновано індивідуальні траєкторії навчання «з урахуванням національно-культурних 
особливостей, базової освіти і рівня мовної підготовки іноземних студентів» [12, c. 17].

Формуванню комунікативної компетентності майбутніх студентів-іноземців у допрофесійній підготовці присвячене дисертаційне дослідження О. Коротун (2012). Дослідниця робить акценти на теоретичному обгрунтуванні та експериментальній перевірці педагогічних умов формування зазначеної компетентності, визначенню іiі критеріїв, показників, рівнів сформованості, пропонує своєрідну структурну модель та методику іiї формування. У руслі наукової розробки заявленої проблеми помітним $\epsilon$ і дослідження I. Аль-Шабуля (2012), присвячене формуванню та педагогічним умовам формування комунікативних якостей іноземних студентів у процесі навчальної діяльності, проте, ця робота не закцентована безпосередньо на етапі допрофесійної підготовки студентів-іноземців.

Питання формування професійно-мовної компетентності іноземних студентів на етапі довишівської підготовки розглянуте в дисертації С. Іонкіної (2012). Серед здобутків російського педагога можна виокремити: визначення професійно-мовної компетентності іноземного студента, розроблення динамічної багаторівневої моделі формування вказаної компетентності, визначення умов, принципів та логіки іiі формування.

I. Сладких (2014) дослідила формування готовності студентів-іноземців груп довишівської підготовки до навчання у вищих технічних навчальних закладах.

Я. Проскуркіна (2014) пропонує модель допрофесійної підготовки іноземних абітурієнтів медичного профілю, яка, на нашу думку, реалізує деякі концепти моделі О. Суригіна. Дослідниця визначає такі ii складники: стрижневий цільовий блок; методологічний блок, що містить як підходи до навчання іноземних абітурієнтів (компетентнісний, комунікативно-когнітивний i особистісно-орієнтований), так i принципи навчання (принцип гуманізації навчального процесу, принцип компетентнісної спрямованості змісту навчальних дисциплін, комунікативнокогнітивний принцип навчання мови, принцип наступності); навчально-методичний блок (розгляд пріоритетних практичних завдань, визначення педагогічних умов i засобів реалізації моделі) [7, с. 144-145]. Авторка наголошує, що модель буде ефективною за дотримання відповідних педагогічних умов, 3-поміж яких: професійноорієнтоване викладання мови, інтеграція і взаємодія дисциплін гуманітарного i природничого блоків, внесення соціокультурного компонента до змісту навчання, системний моніторинг і контроль процесу допрофесійної підготовки [7, с. 145-146]. Кінцева мета запропонованої моделі- забезпечення ефективної навчальнопрофесійної діяльності іноземних студентів [7, с. 147].

Визначивши допрофесійну підготовку іноземців як «процес формування та вдосконалення установок на майбутню діяльність, на здобуття та засвоєння необхідних знань та навичок для ї̈ здійснення, який систематизовано й змістовно організовано згідно культурно-психологічних особливостей громадян іноземних держав» [1, с. 245], А. Бєлоус (2013) бачить іiі передусім різновидом культурнополітичної інтеграції. Науковець аналізує культурні особливості історичних чинників допрофесійної підготовки іноземців (зокрема, медиків) в Україні і доводить залежність цього процесу від культурно-цивілізаційних ареалів [1, с. 249].

Систему педагогічної підтримки адаптації іноземних студентів до навчання у ВНЗ України обгрунтовує Сін Чжефу (2015). На його думку, ця система складається із поєднання цільового, змістово-технологічного, моніторингового та результативного блоків [9, с. 10]. Педагогічними умовами для ï ефективної реалізації є: підготовка педагогічного колективу до роботи в умовах педагогічної підтримки іноземних 
студентів, створення полікультурного соціально-педагогічного середовища, спрямованого на організацію міжкультурного діалогу, формування толерантних відносин тощо [9, с. 10]; а результатом упровадження - особистість іноземного студента з високим рівнем адаптованості [9, с. 12].

Аналітичний огляд доступних дисертаційних досліджень та наукових публікацій останніх 15 років, присвячених проблемам допрофесійної підготовки іноземних студентів, дозволяє зробити наступні висновки. По-перше, є підстави стверджувати, що, хоча у вітчизняній педагогіці питанню допрофесійної підготовки іноземних студентів присвячено ряд грунтовних дисертаційних праць, усе ж це переважно дослідження кандидатського рівня (або наукові публікації), а от концептуальних досліджень рівня докторської дисертації, на жаль, лише одиниці (можливо, тому теоретичною базою сучасних педагогічних досліджень часто стають закордонні концептуально-педагогічні джерела).

По-друге, проблеми допрофесійної підготовки іноземних студенів, сформульовані й досліджені відповідно до вимог спеціальності 13.00.04 («Теорія та методика професійної освіти») в Україні останніх 15 років кількісно представлені небагатьма, i, знову ж таки - переважно кандидатськими дисертаціями. Загалом їх можна погрупувати так: підготовка 3 природничих дисциплін (Н. Булгакова, Т. Шмоніна); розвиток пізнавальних потреб (О. Резван); підготовка до вивчення професійно-технічної лексики (О. Палка); формування комунікативної компетентності (О. Коротун, І. Аль-Шабуль); формування готовності до навчання у ВНЗ України (І. Сладких, Я. Проскуркіна).

Питання допрофесійної підготовки іноземних студентів, викладені відповідно до вимог цієї ж спеціальності в російській науковій практиці у розглянутий період, представлені працями О. Суригіна, Л. Куришевої, В. Кузьмінова, Є. Хачатурової, $€$. Іонкіної, ін. Саме до концептів цих досліджень найчастіше апелюють вітчизняні педагоги.

Ряд праць українських педагогів, хоча й достатньо грунтовно розкривають проблеми допрофесійної підготовки іноземних студентів, проте, відповідають іншим педагогічним спеціальностям (Є. Степанов, Т.Дементьєва, Н. Ушакова, Д. Порох, Сін Чжефу, ін.).

Отже, недослідженими або несистематизованими лишаються досить багато аспектів допрофесійної підготовки іноземних студентів, і потреба в їхній глобалізації і сконденсованості в межах грунтовного дослідження на сьогодні не втратила актуальності. На жаль, обсяги статті не надали нам можливості повніше висвітлити сучасний стан розроблення заявленої проблеми, однак перспективність роботи в цьому напрямі переконлива і визначається закономірностями розвитку педагогічної науки як такої.

\section{Література}

1. Бєлоус А. Ю. Про культурні особливості історичних чинників допрофесійної підготовки іноземних студентів в Україні (на прикладі медичної освіти)/ А. Ю. Бєлоус // Вісник ЛНУ імені Тараса Шевченка. Педагогічні науки. - № 11 (270) Ч. II. - 2013. - $\quad$ C. 245-251. 2. Дементьсва T. I. Формування комунікативної компетенції студентів-іноземців підготовчих факультетів у процесі навчання : автореф. дис. на здобуття наук. ступеня канд. пед. наук : 13.00.09 / Т. І. Дементьєва Харків, 2005.- 19 с. З. Коломієць В. С. Формування професійних мовленнєвих умінь у студентів іноземного походження засобами комплексних дидактичних ігор : автореф. дис. на здобуття наук. ступеня канд. пед. наук : 13.00 .04 / В. С. Коломієць.К., 2001. - 22 с. 4. Кузьминов В. И. Проектирование процессной модели развития 
информационно-компьютерной готовности иностраных студентов к обучению в российских вузах : автореф. дис. на соискание учёной степени канд. пед. наук. : 13.00.08. / В. И. Кузьминов. - Калининград, 2007. - 26 с. 5. Курышева Л. О. Формирование готовности иностранных студентов инженерных специальностей к обучению в российских вузах : дис. ... канд. пед. наук. : 13.00.08. / Л. О. Курышева. Калининград, 2004. - 20 с. 6. Порох Д. О. Соціально-педагогічні умови адаптації іноземних студентів до навчання у вищих медичних навчальних закладах України : автореф. дис. на здобуття наук. ступеня канд. пед. наук : 13.00 .05 / Д. О. Порох. Луганськ, 2011. - 20 с. 7. Проскуркіна Я. І. Модель допрофесійної підготовки іноземних абітурієнтів медичного профілю// Я. І. Проскуріна/ Освіта дорослих: теорія, досвід, перспективи. - Вип. 7. - 2013. С. 143-149. 8. Резван О. О. Педагогічні умови розвитку пізнавальних потреб іноземних студентів у процесі навчання : автореф. дис. на здобуття наук. ступеня канд. пед. наук : 13.00.04 / О. О. Резван. - К., 2008. - 19 с. 9. Сін Чжефу. Педагогічна підтримка адаптації іноземних студентів до навчання у вищих навчальних закладах України : автореф. дис. на здобуття наук. ступеня канд. пед. наук: 13.00.05/ Сін Чжефу. - Старобільськ, 2015. - 20 с. 10. Степанов С. П. Формування культури міжетнічних відносин у студентів вищих навчальних закладів : автореф. дис. на здобуття наук. ступеня канд. пед. наук : 13.00.07 / Є. П. Степанов. - Луганськ, 2004. - 20 с. 11. Сурыгин А. И. Основы теории обучения на неродном для учащихся языке / А. И. Сурыгин. - СПб. : Златоуст, 2000. 230 c. 12. Шмоніна Т. А. Педагогічні умови природничо-наукової підготовки іноземних студентів на підготовчих факультетах вищих навчальних закладів : автореф. дис. на здобуття наук. ступеня канд. пед. наук : 13. 00. 04. / Т. А. Шмоніна. Тернопіль, 2012. - 20 с.

УДК 378.6:614.253.5:616-052-053.9(410)

Юлія Гребеник

\section{КОМУНІКАТИВНА ПІДГОТОВКА МЕДИЧНИХ СЕСТЕР ВЕЛИКОЇ БРИТАНІЇ ДЛЯ РОБОТИ З ПАЦІЕНТАМИ ПОХИЛОГО ВІКУ ТА ПСИХІЧНОХВОРИМИ}

Гребеник Ю. С. Комунікативвна компетенція медичних сестер Великої Британії для роботи з пацієнтами похилого віку та психічнохворими.

У статті розглянуто основні комунікативні вимоги, що висуваються до медичних сестер Великої Британії, які працюють 3 пацієнтами похилого віку та психічнохворими. Надано визначення поняттю «комунікативна культура» та «комунікативна підготовка». Визначено основні рекомендації, які є прийнятними для роботи медичних сестер України з пацієнтами похилого віку та психічнохворими.

Ключові слова: комунікативна підготовка, комунікативна культура, комунікативні вимоги, медична сестра, робота 3 психічнохворими, робота 3 пацієнтами похилого віку.

Гребеник Ю. С. Коммуникативная подготовка медицинских сестер Великой Британии для работы с пациентами пожилого возраста и психическибольными.

В статье рассмотрены основные коммуникативные требования, которые выдвигаются к медицинским сестрам Великой Британии, работающих с пациентами пожилого возраста и психическибольными. Даны определения понятиям «коммуникативная культура» и «коммуникативная подготовка». Определены основные рекомендации, которые являются приемлемыми для работы медицинских 